\title{
Alginases from Azotobacter species
}

\author{
LynN KenNedy, KenNeth McDowell and IAN W. Sutherland* \\ Institute of Cell and Molecular Biology, Division of Biology, Edinburgh University, Edinburgh EH9 3JH, UK
}

(Received 5 March 1992; revised 27 May 1992; accepted 24 July 1992)

\begin{abstract}
Alginate lyases (alginases) have been prepared from strains of Azotobacter vinelandii and Azotobacter chroococcum in which they were located in the periplasm. The enzymes are present in wild-type strains of each species and in mutants failing to encyst or produce bacterial alginate. The lyases have been partially purified by ion exchange chromatography and by affinity chromatography on a matrix prepared from poly-D-mannuronic acid. Although several bacterial and algal alginate preparations were degraded by the enzymes, highest activity was found on poly-D-mannuronic acid or on algal alginates with high mannuronic acid content. The major product from enzymes of either bacterium was an unsaturated uronic acid, when either alginates or poly-D-mannuronic acid were used as substrates. When tested against a series of algal alginates of increasing D-mannuronic acid content, the enzyme activity was highest against alginates of high D-mannuronic acid content, indicating that the enzymes are endo-D-mannurono-lyases. The alginases from the two bacterial species are not identical in their substrate specificity although both show the same generalized type of action.
\end{abstract}

\section{Introduction}

Alginases are of widespread occurrence, being found in marine gastropods, in bacteriophage, in various marine micro-organisms (Doubet \& Quatrano, 1984; Sutherland \& Keen, 1981; Brown \& Preston, 1991) and in some soil Bacillus species (Hansen et al., 1984). Although few of these enzymes have been purified, they have been shown to be endo- or exo-enzymes with specificity towards $\beta$-Dmannuronosyl or $\alpha$-L-guluronosyl linkages. Without exception, the alginases described from these sources have been lyases (eliminases), yielding products with an unsaturated uronic acid at the non-reducing terminus. Although some of the bacteria produce exopolysaccharide, none form alginate. Bacterial alginate synthesis is a feature of certain Pseudomonas aeruginosa isolates, plant pathogenic and other Pseudomonas spp. and of Azotobacter vinelandii and Azotobacter chroococcum (Evans \& Linker, 1973; Osman et al., 1986; Cote \& Krull, 1988). In the Azotobacter species, alginate synthesis is essential for the formation of the desiccation-resistant microcysts produced when the bacteria are subjected to nutrient deprivation and other physiological conditions. The microcysts of $A$. vinelandii contain three types of alginate differing in D-mannuronic acid:L-guluronic acid ratios

\footnotetext{
* Author for correspondence. Tel. (031) 6505331 ; fax (031) 6505392.
}

Abbreviations: EPS, exopolysaccharide; TBA, thiobarbituric acid. and in $O$-acetylation, while $A$. chroococcum strains produce both alginate and other polysaccharides (Page \& Sadoff, 1975). Gacesa (1987) has suggested that alginate lyases and the epimerases which at the polymer level convert D-mannuronosyl residues to L-guluronosyl residues have a common mechanism of action, although this has been disputed by Feingold \& Bentley (1987).

Several of the bacteria that synthesize alginate-like exopolysaccharides also produce alginate lyases but cannot use the polymers as sole carbon and energy source. There is no evidence to suggest that the bacterial alginate serves as a carbon and energy reserve for the bacterial cells which produce this polysaccharide. As relatively few bacteria synthesize polysaccharides and the specific polysaccharases which degrade them, investigation of the alginases from Azotobacter species may provide information on the characteristics and role of such enzymes.

\section{Methods}

Bacteria and culture. Various strains of A. vinelandii (NCIB 8789, Wyss, 206 and UW) and $A$. chroococcum (NCIB 8002 and 8003, Ac 34, 46, 184 and 186) were used for the major experiments. Strains UW and 206 do not encyst. A range of other strains tested initially were either laboratory strains or exopolysaccharide-negative (EPS-) mutants. Several of the strains (Ac) were kindly provided by Professor W. Page (University of Alberta, Canada) (Page, 1986). Two strains of Beijerinckia indica were also examined. The bacteria were grown in 


\section{Table 1. Composition and diad frequencies of some of the bacterial and algal alginates used in this study}

The analyses were by NMR using a Jeol FX-100 spectrometer run at $90^{\circ} \mathrm{C}$ and at $100 \mathrm{MHz}$ as indicated by Skjak-Braek et al. (1986).

\begin{tabular}{lllllll}
\hline \hline \multicolumn{1}{c}{ Source } & $F_{\mathrm{G}}$ & $F_{\mathrm{M}}$ & $F_{\mathrm{GG}}$ & $F_{\mathrm{MM}}$ & $F_{\mathrm{GM}, \mathrm{MG}}$ & Acetyl \\
\hline Laminaria hyperborea & 0.665 & 0.335 & 0.558 & 0.228 & 0.107 & 0 \\
Macrocystis pyrifera & 0.41 & 0.59 & 0.24 & 0.42 & 0.17 & 0 \\
Azotobacter vinelandii 73 & 0.561 & 0.439 & 0.372 & 0.25 & 0.189 & $11 \%$ \\
Azotobacter vinelandii 206 & 0.08 & 0.92 & 0.03 & 0.87 & 0.05 & $24 \%$ \\
Pseudomonas aeruginosa $\mathrm{B}$ & 0.16 & 0.84 & 0 & 0.68 & 0.16 & $37 \%$ \\
\hline
\end{tabular}

Norris's (1959) modification of Burk's nitrogen-free medium supplemented with either $0 \cdot 1 \%(\mathrm{w} / \mathrm{v})$ mannitol or $2 \%(\mathrm{w} / \mathrm{v})$ glucose, or in a similar medium containing $0.1 \%(\mathrm{w} / \mathrm{v})$ casein hydrolysate and $0.1 \%$ $(w / v)$ yeast extract as sources of fixed nitrogen and with $1 \%(w / v)$ mannitol as carbon source. Cultures were grown in Erlenmeyer flasks with less than half the nominal volume of medium and shaken at 200 300 r.p.m. at $30^{\circ} \mathrm{C}$ on an orbital shaker. Bacteria were harvested by centrifugation, washed twice with water and used as a source of enzymes. Total lyase activity was measured in the supernate of ultrasonic lysates of the bacteria after ultracentrifugation at $100000 \mathrm{~g}$ for $30 \mathrm{~min}$, concentration against polyethylene glycol (mol. mass $6000 \mathrm{Da})$ and dialysis against water. Alginates $(10-20 \mathrm{mg})$ were dissolved in water and incubated with samples of lysates or other enzyme preparations. No increase in lyase activity was obtained when $0.1 \%(\mathrm{w} / \mathrm{v})$ sodium alginate was added to the medium and the bacteria were incapable of growth on alginate as sole carbon and energy source.

Cysts of Azotobacter were induced by harvesting cells grown for $48 \mathrm{~h}$ in Norris medium with mannitol as carbon substrate, centrifuging in sterile centrifuge bottles, washing aseptically and resuspending in Norris nitrogen-free medium containing $\beta$-hydroxybutyric acid $(0 \cdot 3 \%$, $w / v)$ as carbon source. The cultures were then shaken at $30^{\circ} \mathrm{C}$. Complete and fairly synchronous encystment was achieved within $48 \mathrm{~h}$. The cysts were then broken by sonication, ultracentrifuged and the supernatant was tested for enzyme activity. Abortive cysts were obtained by transferring cells into $\mathrm{Ca}^{2+}$-free Norris medium and incubated under the same conditions as were used for obtaining normal cysts (Sadoff, 1975).

Enzymes and assay procedures. Enzymes were released by lysis of the bacterial cells either by ultrasonic treatment using $4 \times 1$ min exposures (MSE ultrasonic generator) or by liberation of the periplasmic contents according to the procedure of Osborn et al. (1972). The enzymes were subsequently purified by conventional techniques. Cysts were lysed by treatment with EDTA or EGTA in Tris/ $\mathrm{HCl}$ buffer $(\mathrm{pH} 7.8)$ followed by ultrasonic treatment. Lyase activity was measured using the thiobarbituric acid (TBA) assay technique (Weissbach \& Hurwitz, 1958) for unsaturated uronic-acid-containing products. Alkaline phosphatase was assayed using $o$-nitrophenyl phosphate as substrate and the nitrophenol released was measured at $405 \mathrm{~nm}$. Enzymes were isolated and purified by standard techniques, except that an affinity matrix was prepared by coupling poly-D-mannuronic acid to activated Sepharose. This was performed essentially according to the procedure described by Skjak-Braek \& Larsen (1985) for the purification of an alginate epimerase from $A$. vinelandii. Protein was measured by the Bradford (1976) procedure using a kit from Bio-Rad and the method was as described by the manufacturers. Elution from the affinity matrix and from DEAE-Sepharose columns was achieved by using a linear gradient of increasing $\mathrm{NaCl}$ concentration $(0-0.5 \mathrm{M})$. Protein was monitored at $280 \mathrm{~nm}$.
Substrates. The substrates tested were homopolymeric sequences of poly-D-mannuronic acid and poly-L-guluronic acid, algal alginates of known mannuronic acid:guluronic acid ratio, and some bacterial alginates. The bacterial alginates were prepared in the laboratory, as were the homopolymeric sequences. Algal alginates were either purchased from Sigma or were gifts from various workers. The polymannuronic acid, polyguluronic acid and 'mixed' blocks were prepared from commercial algal alginate from Laminaria by partial acid hydrolysis using the procedure of Penman \& Sanderson (1972). Deacetylated bacterial polysaccharides were prepared by treatment with $0 \cdot 1 \mathrm{M}$-ammonia at $60^{\circ} \mathrm{C}$ for $30 \mathrm{~min}$, dialysis and lyophilization. The detailed composition of the major substrates used, where known, is given in Table 1. The composition and frequency of occurrence of adjacent residues of mannuronic acid or guluronic acid (MM or GG diad frequency respectively) were determined by the NMR techniques of Skjak-Braek et al. (1986). Other algal alginates were of known mannuronic acid content but not of known sequence or diad frequency. Acetyl determination was by the procedure of Hestrin (1949). Products of enzyme degradation were recovered in the diffusate from dialysis of digest mixtures and characterized by HPLC using SAX columns in a Gilson system with refractive index monitoring and $0.005 \mathrm{M}-\mathrm{H}_{2} \mathrm{SO}_{4}$ as eluant (mobile phase). Descending paper chromatography with a mobile phase composed of ethyl acetate/acetic acid/formic acid/water $(18: 3: 1: 4$, by vol.) was also used. The sugars and oligosaccharides were revealed with alkaline silver nitrate reagent. The uronic acid content of oligosaccharides was determined by the procedure of Blumenkrantz \& Asboe-Hansen (1973).

All assays were performed in triplicate and repeated approximately ten times, as were the purification procedures for which representative examples are shown.

\section{Results}

\section{Occurrence and location of alginate lyase activity}

Preliminary tests on a number of wild-type and EPS strains of Azotobacter vinelandii and A. chroococcum revealed that all possessed some alginate lyase activity as measured by increased release of TBA-positive material following incubation of cell lysates with algal alginate from either Laminaria or Macrocystis. Extracts of Beijerinckia indica NCIB 8005 and 8597 were inactive. Some strains of each Azotobacter species consistently produced more enzyme activity than others under 


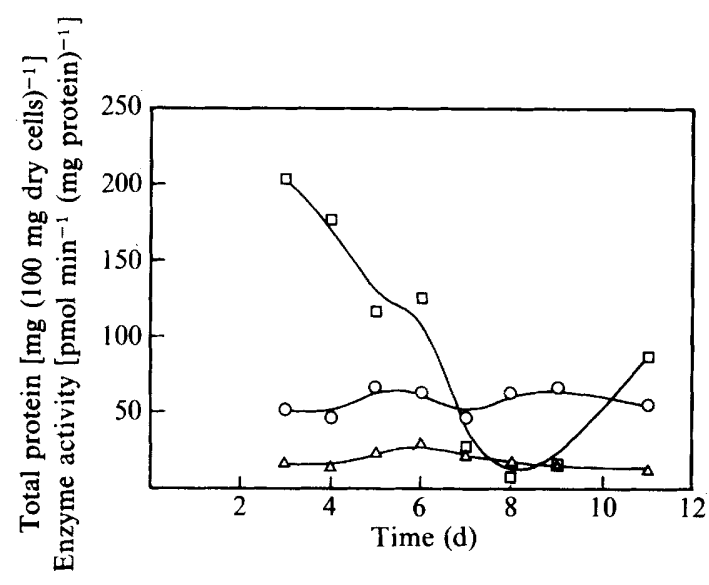

Fig. 1. Production of alginate lyase in $\boldsymbol{A}$. vinelandii during encystment. Cells were transferred to medium containing $\beta$-hydroxybutyrate at $3 \mathrm{~d}$ and started to encyst after a further 6-12 h. Cysts were allowed to germinate after $7.5 \mathrm{~d}$, by addition of $1 \%$ glucose to the medium. $\square$, Alginate lyase; $\triangle$, alkaline phosphatase; $O$, total protein.

standardized culture conditions. Enzyme activity also depended on the growth medium used. It was high in bacteria grown in either Norris medium or semisynthetic medium with glucose or mannitol as carbon substrate. However, lysates of cells grown in medium with sodium glutamate or casein hydrolysate as the major carbon source or in peptone, revealed little lyase activity. As there appeared to be no significant difference in yield between alginate ${ }^{+}$and alginate ${ }^{-}$strains, the latter were used for ease of handling in all subsequent studies and were grown in glucose-containing media.

Tests on the wild-type and EPS ${ }^{-} \boldsymbol{A}$. vinelandii strains clearly revealed that almost all the alginate lyase activity $(93 \%)$ was located in the periplasm, the remainder being extracellular or cytoplasmic. Extracellular enzyme activity was greatest in older cultures $(>5 \mathrm{~d})$ in which considerable cell lysis had occurred. No significant lyase enzyme activity was associated with the cytoplasm. Similar results were obtained for the corresponding fractions from $A$. chroococcum. The enzyme activity in $A$. vinelandii rapidly reached a maximum in the exponential phase of cultures grown in medium with a fixed nitrogen source. Thereafter it declined. In nitrogen-free medium, activity was again high in the exponential phase but did not decline greatly during the early stationary phase. Activity was highest in cells grown on glucose or mannitol as carbon source. Enzyme activity decreased rapidly following induction of cyst formation in the bacteria and reappeared when germination of the cysts was promoted by addition of fresh glucose or mannitol (Fig. 1). This was in contrast to alkaline phosphatase and total protein levels, which remained relatively constant throughout the morphological changes. During encyst- ment, some alginate lyase activity was initially found at a low level in the culture supernatant but this activity disappeared as the cysts matured. Enzyme activity was detected in lysates of abortive cysts induced in $\mathrm{Ca}^{2+}$ deficient medium; the specific activity remained constant and was close to that found in periplasmic material of vegetative cells. The substrate specificity of any alginase activity associated with cysts or abortive cysts did not appear to differ in any of the respects tested from that found in vegetative cells. The $\mathrm{pH}$ optimum of the $A$. vinelandii alginate lyase was 6.8 and the temperature optimum was $30^{\circ} \mathrm{C}$. Alkaline phosphatase, which is known to be a periplasmic enzyme in Pseudomonas aeruginosa (Cheng et al., 1970) was used as a control to ensure that there was no significant contamination of other fractions by periplasmic material.

\section{Enzyme purification}

The enzyme activity was initially precipitated from cell lysates or from periplasmic preparations by addition of ammonium sulphate to $70 \%$ saturation. Slight differences were seen between $A$. vinelandii and $A$. chroococcum after the protein was redissolved; the lyases precipitated with $40 \%$ and $50 \%$ saturation ammonium sulphate respectively. Further purification was attempted using ion exchange chromatography on DEAE-Sepharose (Fig. 2) and using affinity chromatography on a poly-Dmannuronic-acid-based adsorbent (Fig. 3). Although both chromatographic systems yielded some purification as judged by PAGE and by increased specific activity, neither provided pure enzyme. Despite the relatively complex protein elution patterns observed on the affinity matrix, almost all the lyase activity was found in fractions eluting with $30-35 \mathrm{ml}$ of the buffer gradient. The larger amounts of protein eluting with $100-140 \mathrm{ml}$ of buffer were inactive. Some further purification was obtained by pooling the active fractions obtained from ion exchange chromatography and re-running on the affinity column. The failure to obtain pure enzyme from the affinity column was probably because of interaction between bacterial proteins and the polyanionic matrix. The partially purified enzyme preparation from both Azotobacter species showed the same temperature optima of $30^{\circ} \mathrm{C}$. $\mathrm{pH}$ optima were at $\mathrm{pH} 6.8$ and 7.2 respectively for $A$. chroococcum and $A$. vinelandii material.

\section{Substrate specificity}

The partially purified enzymes were also used to determine substrate specificity. For this, a range of algal alginates of known mannuronic acid content was used, 


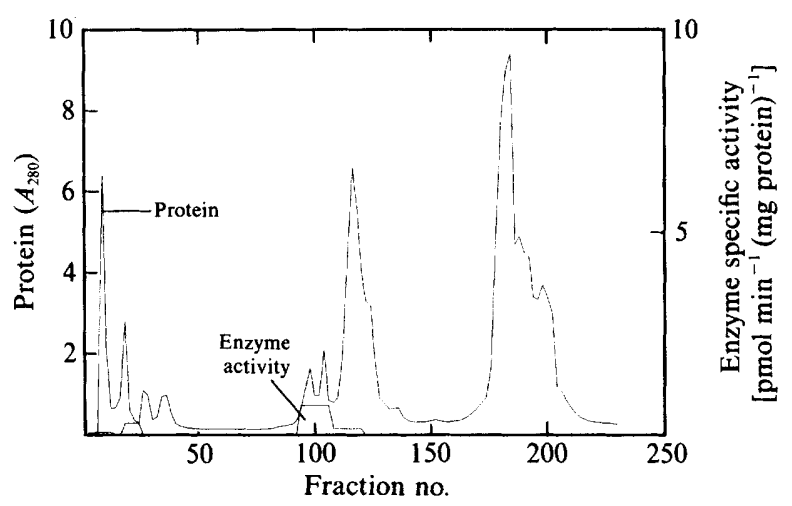

Fig. 2

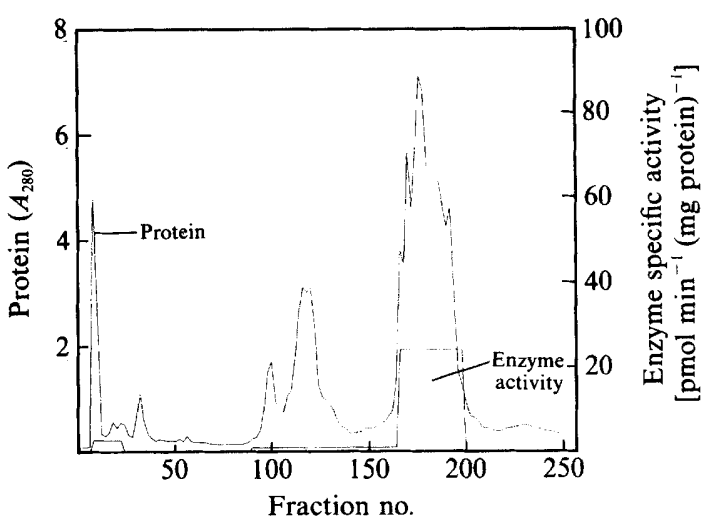

Fig. 3

Fig. 2. Chromatography of $A$. vinelandii (strain UW) periplasm on DEAE-Sepharose. Concentrated periplasmic material (800 $\mu$ l, containing about $5 \mathrm{mg}$ protein) was loaded onto a $20 \times 1 \mathrm{~cm}$ column run in $20 \mathrm{~mm}-\mathrm{Tris} / \mathrm{HCl}(\mathrm{pH} 7.0$ ) with a gradient of $0.5 \mathrm{M}-\mathrm{NaCl}$ applied at fraction $62 ; 1 \mathrm{ml}$ fractions were collected.

Fig. 3. Affinity chromatography of $A$. chroococcum (strain 184) periplasmic material. Concentrated periplasmic material (800 $\mu$, containing about $5 \mathrm{mg}$ protein) was loaded onto a $5 \times 1 \mathrm{~cm}$ column of polymannuronic acid-Sepharose and run with $20 \mathrm{mM}-\mathrm{Tris} / \mathrm{HCl}$ (pH 7.0). A gradient of $0.5 \mathrm{M}-\mathrm{NaCl}$ was started at fraction 68 and $1 \mathrm{ml}$ fractions were collected.
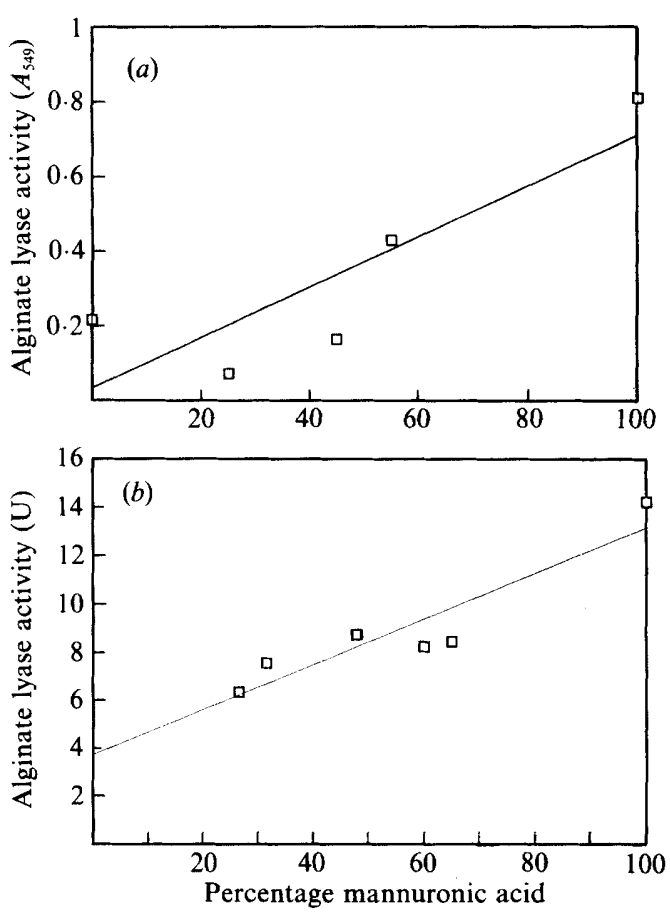

Fig. 4. (a) Substrate specificity of partially purified $A$. vinelandii (strain UW) enzyme. Solutions of alginate $\left(10 \mathrm{mg} \mathrm{ml}^{-1}\right)$ were mixed with about $1 \mathrm{mg}$ semi-purified alginate lyase and incubated at $30^{\circ} \mathrm{C}$ for $7 \mathrm{~h}$. Samples $(100 \mu l)$ were withdrawn in triplicate and assayed by the TBA reaction. Note that on the vertical axis lyase activity is shown as $A_{549}$. (b) Substrate specificity of partially purified $A$. chroococcum (strain 184) enzyme. Experimental methods as in $(a)$. Note that on the vertical axis lyase activity is shown as units, where 1 unit (U) is the activity that liberates $1 \mu \mathrm{mol}$ unsaturated uronic acid $\mathrm{min}^{-1}$. The lines are the best fit to the means of triplicate measurements that varied by $1 \%$ or less. together with poly-D-mannuronic and poly-L-guluronic acid preparations. Naturally, acetylated and chemically deacetylated bacterial alginates were also tested. Preliminary experiments indicated that the activity of enzymes prepared from either Azotobacter strain was greater against some of the algal alginates than against bacterial products from either $A$. vinelandii or $P$. aeruginosa. Under standard conditions, the highest enzyme activity was observed when the substrates were non-acetylated algal alginates of high $\mathrm{D}$-mannuronic acid content (Fig. $4 a, b$ ).

Lyase preparations from either of the Azotobacter species were much more active against an algal alginate preparation than against the native acetylated alginates from $A$. vinelandii or $P$. aeruginosa. The highly acetylated polysaccharides from Pseudomonas or Azotobacter were relatively resistant to enzyme action. Even when the bacterial alginates had been chemically deacetylated, the algal material was normally the favoured substrate but removal of the $O$-acetyl groups clearly enhanced activity considerably. The relative activities of typical semipurified preparations from each Azotobacter species are indicated in Table 2. Very high activity was found when the substrate was an $A$. vinelandii alginate which had previously been subjected to treatment with an alginate lyase from Klebsiella aerogenes having specificity towards guluronosyl linkages (Boyd \& Turvey, 1978). This substrate differed from the native alginates in being of lower molecular mass, as were the polymannuronic acid, polyguluronic acid and 'mixed block' samples prepared by the partial acid hydrolysis procedure of 
Table 2. Relative activities of Azotobacter alginases on algal and bacterial alginates

\begin{tabular}{|c|c|c|}
\hline Alginate & A. vinelandii & A. chroococcum \\
\hline \multicolumn{3}{|l|}{ (a) Algal } \\
\hline Laminaria hyperborea & $0 \cdot 78$ & 0.53 \\
\hline Macrocystis pyrifera & $1 \cdot 0$ & 1.0 \\
\hline M blocks & $0 \cdot 61$ & 0.42 \\
\hline M-G blocks & 0.91 & $0 \cdot 15$ \\
\hline \multicolumn{3}{|l|}{ (b) Bacterial } \\
\hline Pseudomonas aeruginosa $\mathrm{B}$ & $0 \cdot 165$ & 0.28 \\
\hline Pseudomonas aeruginosa B (deac.) & $0 \cdot 4$ & 0.90 \\
\hline Azotobacter vinelandii 206 & $0 \cdot 22$ & $0 \cdot 205$ \\
\hline Azotobacter vinelandii 206 (deac.) & 0.67 & 0.41 \\
\hline Azotobacter vinelandii 73 & $0 \cdot 26$ & $0 \cdot 23$ \\
\hline Azotobacter vinelandii 73 (deac.) & 0.84 & $0 \cdot 39$ \\
\hline
\end{tabular}

Penman \& Sanderson (1972). No detectable difference in specificity was observed for lyase preparations from abortive cysts or from cysts.

The products of alginate degradation were all of low molecular mass. The major product from all substrates was the unsaturated uronic acid deriving from the action of the lyase on the non-reducing terminal D-mannuronosyl residues. This fragment had an $R_{\text {Man A lactone value of }}$ 0.67 on paper chromatography. Some material with a relative mobility of 0.76 was observed in the digests from one of the acetylated bacterial alginates, and this appears to be the corresponding acetylated uronic acid derivative as analysis of the fraction revealed the presence of uronic acid and acetate in approximately equal amounts. In some of the alginates digested for a short time only, small amounts of some slower-moving oligosaccharides were also detected. Digests of 'mixed block' sequences of the two uronic acids consistently yielded small amounts of several oligosaccharides in addition to the unsaturated uronic acid. All these oligosaccharides were TBApositive and the ratio of TBA-positive material to total uronic acid indicated that they were probably disaccharides or trisaccharides in which the unsaturated uronic acid formed the non-reducing terminus.

\section{Discussion}

\section{Occurrence and nature of the alginate lyases}

The alginases found as periplasmic enzymes in $A$. vinelandii and $A$. chroococcum are present in vegetative bacteria and are lost on encystment, but are rapidly resynthesized on cyst germination. The enzymes from both species show specificity towards sequences of mannuronosyl residues. In this, they resemble an enzyme from an $A$. vinelandii phage (Davidson et al., 1977) and enzymes from several Pseudomonas species. The exact specificity is not entirely clear as the alginases may hydrolyse either $\cdots$ ManA-GulA $\cdots$ or $\cdots$ ManAManA $\cdots$ linkages or only the latter. The mode of action of enzymes degrading alginate is further complicated by the differences in distribution of monosaccharide residues in different substrates. Thus, as can be seen in Table 1 , alginates with the same or very similar mannuronic acid:guluronic acid ratios can have very great differences in monosaccharide sequence and in the frequency of adjacent residues.

\section{Specificity of the alginate lyases}

The enzymes from both Azotobacter species are alginate lyases, i.e. they are among the relatively large group of polysaccharide lyases which cleave their substrates by $\beta$ elimination mechanisms (Linhardt et al., 1986). Further, the terminal non-reducing product formed from either D-mannuronosyl or L-guluronosyl residues through the action of an alginate lyase is identical. It is 4-deoxy-Lerythro-hex-4-ene pyranosyluronate. For one enzyme, the guluronate-specific lyase from Klebsiella aerogenes, the initial rate of reaction depends on the concentration of $\mathrm{L}$ guluronosyl residues in solution (Haugen et al., 1990). When tested against substrates with different distributions of the two component uronic acids, initial reaction rates were considerably lower, indicating that the Klebsiella enzyme may either attack one type of linkage or may attack different types at different rates.

The method of preparation of so-called homopolymeric blocks is not sufficiently precise to exclude all heterologous residues and they certainly do contain a small number of heterologous residues. Activity may also be greatly influenced by the nature of residues adjacent to the site of chain cleavage and there may indeed be a requirement for a more heterogeneous structure at or near the site of cleavage in macromolecular substrates. The presence of $O$-acetyl groups on D-mannuronosyl residues appears to be inhibitory to the action of lyase preparations from both species of Azotobacter. These substituents are known from the work of Skjak-Braek $e t$ al. (1986) to be on the 2 and 3 positions, with some $3-11 \%$ of the mannuronosyl residues in some bacterial alginate samples being doubly acetylated. Boyd \& Turvey (1978) demonstrated that cleavage of alternating sequences (mixed blocks) can be accomplished using enzymes with either polymannuronic acid specificity or polyguluronic acid specificity. The products obtained from cleavage of alginate chains by the different lyases also show variation. Some only produce trimer (Preston et al., 1991), while others form a wider range of products (e.g. Davidson et al., 1977). The enzymes from both Azoto- 
bacter species yielded the unsaturated uronic acid monomer as the major product and formed only small amounts of higher oligosaccharides from 'mixed block' material. From the relative activities of the preparations from the two bacterial species, although they have the same specificity in general terms, they are not identical in their reactions. This may reflect the role of residues distal to the site of cleavage of the substrate.

Apart from the alginate lyase associated with $A$. vinelandii phage (Davidson et al., 1977), most of the enzymes of this type that have been described are extracellular enzymes secreted by a diverse range of micro-organisms (e.g. Boyd \& Turvey, 1978; Hansen et al., 1984; Sutherland \& Keen, 1981). As such, the enzymes can probably interact readily with their macromolecular substrates, which are then degraded to provide fragments that can be utilized as carbon and energy sources, feeding into the citric acid cycle as indicated by Preiss \& Ashwell (1962). Few of the enzymes have been purified and extensively characterized, exceptions being the polyguluronic-specific lyase from Klebsiella aerogenes (Caswell et al., 1989) and the mannuronic-specific lyases from two marine bacteria (Davidson et al., 1976; Romeo \& Preston, 1986).

\section{Possible role of the Azotobacter alginate lyase}

The alginate lyases described in the present study differ in that they are located in the periplasm where they would not normally be expected to come into contact with their substrate. They cannot function in enabling the bacteria to utilize alginate as an external polymeric source of carbon and energy and indeed the bacteria are unable to grow on alginate. Their role is more likely to be in differentiation and encystment, where very great changes occur in the bacterial surface polymers (Sutherland \& Mackenzie, 1977). Alginate with differing composition is found in various locations inside and outside the Azotobacter cysts (Sadoff, 1975). However, no change in enzyme specificity was noted following encystment (results not shown). The alginate lyases may play a role in the removal of preformed alginate during differentiation, although our studies show that their activity on the normal highly acetylated EPS is relatively low. Alginate- strains of $\boldsymbol{A}$. vinelandii fail to encyst, but no alginase ${ }^{-}$mutants have yet been reported, so it is not clear whether such mutants are also incapable of encystment or of undergoing some type of morphogenesis.

The authors are grateful to Professor W. Page (University of Alberta) for the gift of a number of the bacterial strains. Dr G. Skjak-Braek and colleagues at the Laboratory of Biotechnology, NTH Trondheim are thanked for the NMR analysis of several of the alginates and determination of their diad frequencies.

\section{References}

Blumenkrantz, N. \& Asboe-Hansen, G. (1973). New method for quantitative determination of uronic acid. Analytical Biochemistry 54, 484-489.

BOYD, J. \& TURVEY, J. R. (1978). Structural studies of alginic acid using a bacterial poly- $\alpha$-L-guluronate lyase. Carbohydrate Research 66, 187194.

BradFord, M. M. (1976). A rapid and sensitive method for the quantitation of microgram quantities of protein utilizing the principle of protein-dye binding. Analytical Biochemistry 71, 248254.

Brown, B. J. \& Preston, J. F. (1991). L-Guluronan-specific alginate lyase from a marine bacterium associated with Sargassum. Carbohydrate Research 211, 91-102.

Caswell, R. C., Gacesa, P., Lutrell, K. E. \& Weightman, A. J. (1989). Molecular cloning and heterologous expression of a Klebsiella pneumoniae gene encoding alginate lyase. Gene 75, 127-134.

Cheng, K-J., Ingram, J. M. \& Costerton, J. W. (1970). Release of alkaline phosphatase from cells of Pseudomonas aeruginosa by manipulation of cation concentration and of $\mathrm{pH}$. Journal of Bacteriology 104, 748-753.

Cote, G. L. \& KRULL, L. H. (1988). Characterization of the exocellular polysaccharides from Azotobacter chroococcum. Carbohydrate Research 181, 143-152.

Davidson, I. W., Surherland, I. W. \& Lawson, C. J. (1976). Purification and properties of an alginate lyase from a marine bacterium. Biochemical Journal 159, 707-713.

Davidson, I. W., Lawson, C. J. \& Sutherland, I. W. (1977). An alginate lyase from Azotobacter vinelandii phage. Journal of General Microbiology 98, 223-229.

Doubet, R. S. \& Quatrano, R. S. (1984). Properties of alginate lyases from marine bacteria. Applied and Environmental Microbiology 47, 699-703.

EVANS, L. R. \& LiNker, A. (1973). Production and characterization of the slime polysaccharide of Pseudomonas aeruginosa. Journal of Bacteriology 116, 915-924.

Feingold, D. S. \& BeNTLEY, R. (1987). Conformational aspects of the reaction mechanisms of polysaccharide lyases and epimerases. FEBS Letters 223, 207-211.

GACESA, P. (1987). Alginate-modifying enzymes. FEBS Letters 212 , 199-202.

Hansen, J. B., Doubet, R. S. \& RaM, J. (1984). Alginase production by Bacillus circulans. Applied and Environmental Microbiology 47, 704709.

Haugen, F., Kortner, F. \& Larsen, B. (1990). Kinetics and specificity of alginate lyases. I. A case study. Carbohydrate Research 198, 101-109.

Hestrin, S. (1949). The reaction of acetylcholine and other carboxylic acid derivatives with hydroxylamine, and its analytical application. Journal of Biological Chemistry 180, 249-261.

Linhard, R. J., Galliher, P. M. \& CoOney, C. L. (1986) Polysaccharide lyases. Applied Biochemistry and Biotechnology 12, 135-176.

NoRRIs, J. R. (1959). The isolation and identification of Azotobacter. Laboratory Practice 8, 239-243.

Osborn, M. J., Gander, J. E., Parisi, E. \& Carson, J. (1972). Mechanism of assembly of the outer membrane of Salmonella typhimurium. Isolation and characterization of cytoplasmic and outer membrane. Journal of Biological Chemistry 247, 3962-3972.

Osman, S. F., FeTt, W. F. \& Fishman, M. L. (1986). Exopolysaccharides of the phytopathogen Pseudomonas syringae pv. glycinae. Journal of Bacteriology 166, 66-71.

PAGE, W. J. (1986). Sodium-dependent growth of Azotobacter chroococcum. Applied and Environmental Microbiology 51, 510-514.

PAGE, W. J. \& SADOFF, H. L. (1975). Relationship between calcium and uronic acids in the encystment of Azotobacter vinelandii. Journal of Bacteriology 122, 145-151.

Penman, A. \& Sanderson, G. R. (1972). A method for the determination of uronic acid sequence in alginates. Carbohydrate Research 25, 273-282. 
Preston, J. F., Rice, J. D., Chow, M. C. \& Brown, B. J. (1991). Kinetic comparisons of trimer-generating pectate and alginate lyases by reversed-phase ion pair chromatography. Carbohydrate Research 215, 147-157.

Romeo, A. \& Preston, J. F. (1986). Purification and structural properties of an extracellular $(1 \rightarrow 4)-\beta$-D-mannuronan specific alginate lyase from a marine bacterium. Biochemistry 25, 8385-8391.

SADOFF, H. L. (1975). Encystment and germination in Azotobacter vinelandii. Bacteriological Reviews 39, 516-539.

SkJaK-Braek, G. \& LaRSEN, B. (1985). Biosynthesis of alginate: purification and characterization of mannuronan C-5-epimerase from Azotobacter vinelandii. Carbohydrate Research 139, 273-283.
Skjak-Braek, G., Grasdalen, H. \& LaRSen, B. (1986). Monomer sequence and acetylation pattern in some bacterial alginates. Carbohydrate Research 154, 239-250.

Sutherland, I. W. \& Keen, G. A. (1981). Alginases from Beneckea pelagia and Pseudomonas spp. Journal of Applied Biochemistry 3, 4857.

Sutherland, I. W. \& MACKenzIE, C. L. (1977). Glucan common to the microcyst walls of cyst-forming bacteria. Journal of Bacteriology 129, 599-605.

Weissbach, A. \& HuRwitz, J. (1958). The formation of 2-keto-3deoxyheptonic acid in extracts of Escherichia coli. Journal of Biological Chemistry 234, 705-709. 